\title{
Enhancing the Performance of PV Panel Undergoing Shading Effects
}

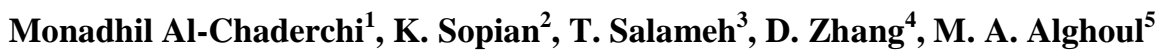 \\ ${ }^{1,3,4}$ Sustainable and Renewable Energy Engineering Department, College of Engineering, University of Sharjah, Sharjah, \\ United Arab Emirate \\ ${ }^{2}$ Solar Energy Research Institute, University Kebangsaan Malaysia, Selangor, Malaysia \\ ${ }^{5}$ Center of Research Excellence in Renewable Energy (CoRERE), Research Institute, King Fahd University of Petroleum \\ and Minerals (KFUPM), Saudi Arabia
}

\begin{tabular}{|c|c|}
\hline Article Info & ABSTRACT \\
\hline Article history: & \multirow{10}{*}{$\begin{array}{l}\text { Experimental and simulation work were performed to study the effects of } \\
\text { shading for different strings inside photovoltaic (PV) panels under real } \\
\text { outdoor environmental climate conditions for Sharjah, United Arab Emirates. } \\
\text { The electrical characteristics of PV panel were measured by using the PV } \\
\text { analyzer, while the simulations were performed by MATLAB. The effect of } \\
\text { full cell shading were studied experimentally for each configuration of two or } \\
\text { four bypass diodes and verified by theoretical modeling. The I-V and P-V } \\
\text { curves for all cases were recorded to investigate the effect of bypass diodes } \\
\text { in reducing shading losses under similar environmental conditions. } \\
\text { Compared to design with fewer bypass diodes, inserting more bypass diodes } \\
\text { (four diodes in our work) contributed to higher yield in performance of solar } \\
\text { PV panels undergoing shading while taking in to account the cost of energy } \\
\text { production. Compared to the case of two bypass diodes, applying four diodes } \\
\text { can recover up to } ~ 31 \% \text { of non-shaded maximum power under different cell } \\
\text { shading conditions. }\end{array}$} \\
\hline Received Apr 12, 2018 & \\
\hline Revised Sep 12, 2018 & \\
\hline Accepted Sep 24, 2018 & \\
\hline Keyword: & \\
\hline Bypass diode & \\
\hline Full shading & \\
\hline MATLAB modeling & \\
\hline PV solar panel & \\
\hline Shading & \\
\hline
\end{tabular}

Copyright $\odot 2018$ Institute of Advanced Engineering and Science. All rights reserved.

\section{Corresponding Author:}

Monadhil Al-chaderchi,

Sustainable and Renewable Energy Engineering Department,

University of Sharjah, Sharjah, United Arab Emirate.

Emmail: malchadirchy@sharjah.ac.ae

\section{INTRODUCTION}

Photovoltaic (PV) renewable energy systems are widely used as a source of green energy because its ability to convert solar energy directly to electrical energy with low carbon footprint on the environment. The maturity of the PV technologies enables this source of renewable energy to compete strongly with traditional energy systems. The performance of PV energy systems is affected dramatically by shading phenomena, which can be seen clearly on theshort-circuit current and maximum power production from PV panels. Shading can happen for different reasons which are usually related to atmospheric and surrounding conditions such as dust, shadows due to tall buildings, tall communication towers, plants, birds, waste of birds and insufficient space between the strings of PV panels in a PV array. Shading is categorized into two main types: (i) full shading and (ii) partial shading.

Addressing the performance of PV a system under partial shading is highly relevant to enhancing system performance, since partial shading happens much more often than full shading. Simulations and experiment studied have been reported using different models to study the effect of partial shading on solar cell, PV module and array in order to mitigate the effect of partial shading. For instance, the control algorithms for maximum power point tracking (MPPT) can be optimized and designed for scenarios under partial shading [1]-[3]. The worst case shading scenarios for a micro inverter system were presented by study of [4]. In this study a two-stage system architecture was used to module level partial shading. In reference [5] 
the authors performed simulation for shading effects in arrays with different string configurations based on solar cell. A generalized PV module model in MATLAB was developed based on the mathematical equation of PV cell [6]. The model is used to simulate partially shaded cells in the PV module and also for partial shaded modules in the PV string under various weather conditions. In the study [7], the behavior of a photovoltaic device (cell or module) under partial shading conditions were reviewed and analyzed by using MATLAB. In the study [8], MATLAB/Simulink was used to design and simulate a complete off-grid PV module based power generation system. The value of standard solar irradiance about $1 \mathrm{~kW} / \mathrm{m}^{2}$ was used for Bangladesh. The simulation model was examined the performance of all components (blocks) for the off-grid PV module system. Adaptive inertial weight particle swarm optimization (AIWPSO) algorithm was proposed to solve the low convergence speed and search accuracy of the Particle swarm optimization (PSO) under partially shading by the study of [9]. In the study of [10], firefly algorithm was used to record the development of a maximum power-point tracking (MPPT) method for photovoltaic (PV) systems under partially shaded conditions.

The effect of insolation on the array performance in terms of uniformity and amount were studied by [11], [12]. In the study of [11], the $I-V$ and $P-V$ characteristics of a PV array under a non-uniform insolation due to partial shading were presented based on modeling and simulation scheme performed by MATLAB. The impact of shading on array characteristics using MATLAB model of PV array were observed by the study of [12]. Different insolation incident were considered on different models. The output of the MATLAB model with the theoretical values was compared. The goal of this study is to design and develop simulation of solar panels connected in series integrated with a boost converter and MPPT algorithm taking into account the effects of partial shading.

A novel control strategy was proposes by [13], in which a control system allows partially shaded photovoltaic power plants (PV-PPs) to mitigate the effects on the frequency of power systems without need an energy storage. Another study for the topology of PV power generation system was proposed by [14], where the PV module connects with capacitor in each sub-module of a modular multilevel converter in parallel, with the maximum power extracted by regulating the capacitor voltage to the maximum power point voltage during partial shading. In the study [15] diode was replaced with an element of resistance in the simulation model. The results shows that the open circuit voltage of the PV module with a damaged bypass diode was slightly higher than that of a PV module under shading conditions while the PV system was operating.

Some researchers compared simulation with experimental work for the same conditions in order to validate their results. The partially shadowed simulation and modeling procedure for both solar cells and PV modules (209 Wp from Siliken) were presented by P-spice environment in [16], and the simulation results were compared with real measured data. In reference [17], they studied the impact of using bypass diodes on the solar cell performance under shading at a module level. Algorithm based on MATLAB was designed to study the effects of non-overlapping bypass diode configuration in a randomly shaded solar module. In the work of [18] the effect of partial shading on the $I-V$ curve and the maximum power point (MPP) for multicrystalline PV modules (mc-Si) were simulated by P-Spice, The simulation results used to derive generalized formulae for evaluation voltage and power at MPP and validated with experimental results. In the work of [19], based on their simulation and experimental results, the proposed system demonstrated the possibility of enhancing the PV array's extracted output power during partial shading. Different changes were made to the internal interconnection of the solar panels in [20]. Various tests were carried out under different effects of shading to study the effect of bypass diodes on the output power of the solar panel.

Different parameters related to the shading phenomena such as number of bypass diode, type of connection (series and parallel) and the interconnection scheme were previously investigated. For example the effect of implementing an enhanced version of the widely used single-diode was studied in [21], where the electrical response of a partially shaded photovoltaic (PV) array including several string connected in parallel was simulated. In [22], [23], they investigated the harmful effects of partial shading of series and parallel connected PV modules and compare their performance. In the study of [24], the effects of bypass diodes and the variation of the equivalent circuit parameters with respect to operating conditions was considered in the model. In study of [25], fixed interconnection scheme was presented for PV arrays in order to enhance the PV power under different shading conditions. Experimental work for measurement the I-V and power curves were done in [26] for two and four bypass diodes under fully cell shaded module.

While the previously mentioned works covered the shading effects from different aspects, no reports studied the effect of different configurations of the bypass diodes (i.e. two and four diodes) for cells connected in series (string) in a module. In this paper, the I-V characteristic curve and power performance of a 30-W PV panel under different full cell shading conditions will be studied by using two and four bypass diodes configurations. A PV analyzer device will be used to measure I-V and power curves for the panel.

Int J Pow Elec \& Dri Syst, Vol. 9, No. 4, December 2018 : 1937 - 1943 


\section{SYSTEM MODELING}

We used a modified PV panel model in Simscape. The irradiance and temperature behavior of each of the PV block is described by a five parameter model using a current source, diode, series resistance and shunt resistance. Figure 1 shows one of our models with 4 bypass diodes. Each bypass diode is in parallel connection with one string of solar cells (represented and simulated by a basic PV module in Simscape with internally 9 cells in series), which corresponds to our actual experimental setup of the $30 \mathrm{~W}$ panel using 4 diodes. Partial shading of different number of cells in the $30 \mathrm{~W}$ panel was simulated by lowering the irradiance input to the affected string(s) to a small value $\left(10 \mathrm{~W} / \mathrm{m}^{2}\right)$, while the temperature input was always kept constant. A Simulink output vector was used to collect and display the simulation results to the software output. For other diode configurations, the model in Figure 1 was modified accordingly.

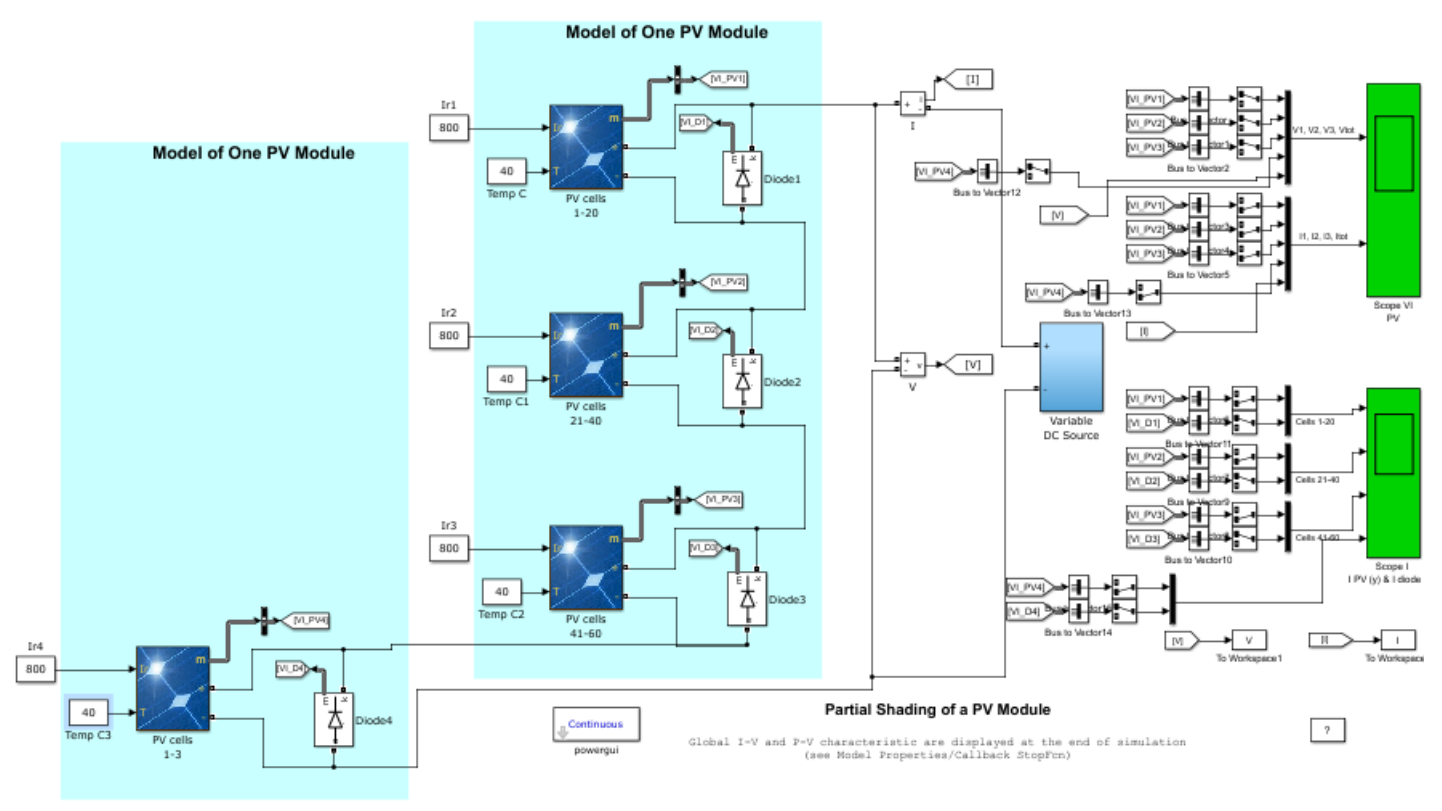

Figure 1. Shaded PV panel model in simscape with 4 bypass diodes

\section{EXPERIMENTAL SETUP}

A PV analyzer (Profitest) setup was used to measure both I-V and power curves for the PV panel as shown in Figure 2. The electrical characteristics of PV panel are shown in Table 1. All the experiments were tested under the real weather conditions of $\operatorname{UAE}$ (i.e. irradiance $\left(\mathrm{W} / \mathrm{m}^{2}\right)$ and ambient temperature $\left({ }^{\circ} \mathrm{C}\right)$. The effect of fully shading on the cell was performed by using cardboard with different configurations of bypass diodes based on two and four diodes. Regarding the accuracy of the experimental setup, the varying irradiance under outdoor environment as well as modifying the diode connection of the panel need to be taken into consideration.

The accuracy of measuring temperature and peak power were $\pm \mathrm{K}$ and $5 \%$ respectively, It worth to mention that, this accuracy for peak power achieved when the amount of irradiance fall on the module was at least $600 \mathrm{~W} / \mathrm{m}^{2}$ and the fluctuating of irradiance not more than $\pm 10 \mathrm{~W}$. 


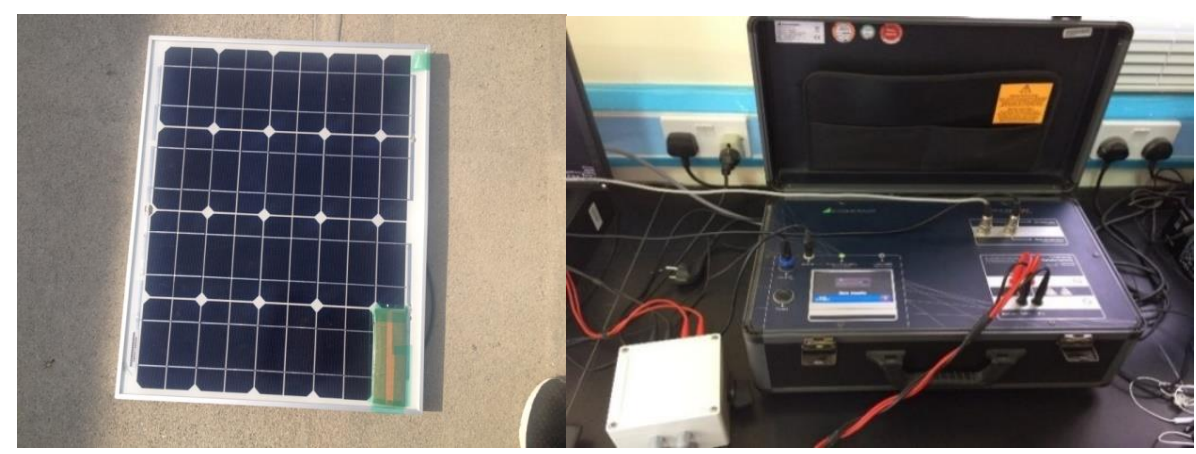

Figure 2. The PV Panel Used in this Study and the PV Analyzer (Profitest) Setup for Measuring I-V and Power Curves for PV Panels

Table 1. Electrical Characteristic of PV Panel Used in the Testing Under Standard Test Condition (STC)

\begin{tabular}{cc}
\hline Open circuit voltage $\left(\mathrm{V}_{\mathrm{oc}}\right)$ & $22.5 \mathrm{~V}$ \\
\hline $\begin{array}{c}\text { Short circuit current }\left(\mathrm{I}_{\mathrm{sc}}\right) \\
\left(\mathrm{V}_{\mathrm{mp}}\right)\end{array}$ & $2 \mathrm{~A}$ \\
Voltage at maximum power point & $18 \mathrm{~V}$ \\
$\left(\mathrm{I}_{\mathrm{mp}}\right)$ & $1.67 \mathrm{~A}$ \\
Current at maximum power point & $30 \mathrm{~W}$ \\
$\begin{array}{c}\text { Maximum power }\left(\mathrm{P}_{\mathrm{mp}}\right) \\
\text { \# of cells and type }\end{array}$ & 36 Monocrystalline \\
\hline
\end{tabular}

\section{RESULTS AND DISCUSSION}

The effect of full cell shading was firstly experimentally studied on a $30 \mathrm{~W}$ PV panel with either 2 or 4 bypass diodes. Figures 3 and 4 show the I-V and P-V curves of the $30 \mathrm{~W}$ panel with 2 bypass diodes under different conditions of fully cell shading including no shading and different number of cells shaded. Since the measurement was performed under real operational conditions with actual irradiance and temperature, the performance of the panel deviated slightly from the rated value (STC). Since only 2 bypass diodes connected to the panel (dividing the solar cells evenly), the panel performance was affected considerably by shading. Compared to reference, when one cell was fully shaded, the voltage and the power of the panel dropped considerably to less than $50 \%$ of the unshaded output. For the case of 2 cells shaded, the panel performance depended on the cell arrangement: if the two shaded cells belong to the same bypass diode (string), the panel output would drop to 50\% similar to the one cell shaded case, since only one bypass diode is operating under forward bias; in other hand, if the two cells belong to different diodes, the panel output will decrease to almost negligible level due to both diodes are conducting as shown in Figure 3 and 4. By adding more cells shaded ( 3 or 4 cells), with only two bypass diodes, the output of the panel would always remain low for similar reasons when both bypass diodes conducting. Therefore, the performance of PV panel with the configuration of only two bypass diodes is quite sensitive to cell shading and not effective remedy.

Then the performance of the $30 \mathrm{~W}$ panel with four diodes configuration under the same condition was studied. As can be seen from Figs. 5 (I-V curves) and 6 (P-V curves), the panel performance became less sensitive to shading when add additional diodes. Comparing the cases between 2 and 4 bypass diodes, we can clearly see the performance gain when using more bypass diodes, as shown in Table 2 and Figure 7 . The power gain in Table 2 was calculated by the difference in the maximum power for 4 diodes and 2 diodes respectively. When using 4 number of diodes, for the case of one cell shading, the panel voltage maintained at $69.6 \%$ instead of only $47.3 \%$ for 2 diodes case of the non-shaded value. With the shading of every subsequent cell (under different diodes), the voltage and thus power drop each time was merely $25 \%$. Hence, this clearly indicates the importance of increase the number of bypass diodes in PV panels against cell shading, this will lead to recover more significantly output power from PV panel and the overall panel cost will slightly increase. 


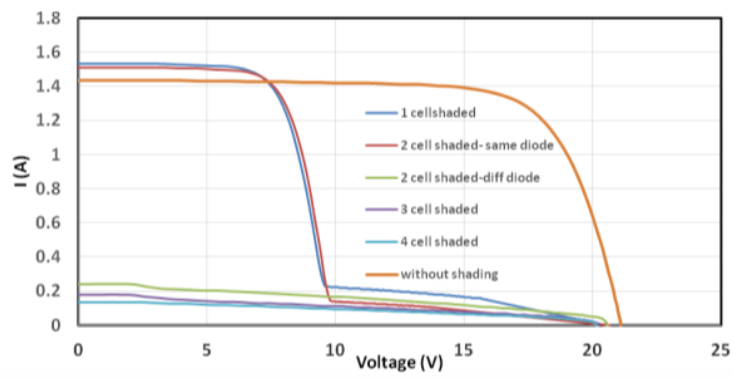

Figure 3. I-V Curves of a $30 \mathrm{~W}$ panel with 2 bypass diodes under different conditions of full cell shading

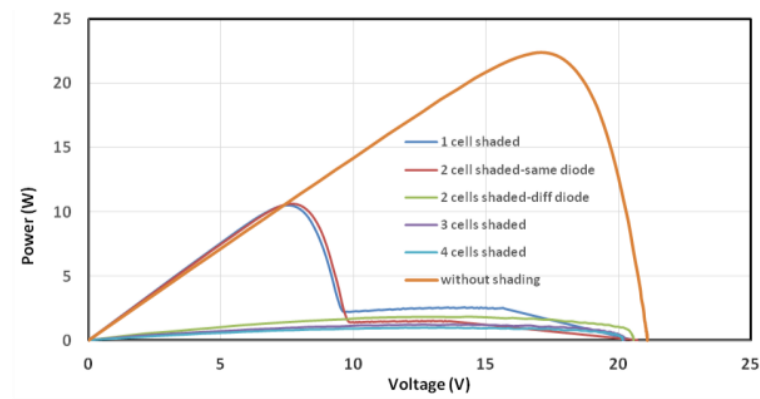

Figure 4. P-V Curves of a $30 \mathrm{~W}$ panel with 2 bypass diodes under different conditions of full cell shading

The simulation model using the Simscape module in Matlab was further conducted to verify the experimental results. A modified model based on the PV array model in Simscape was used in this study, and the algorithm of this model is shown in Figure 1. The shading effect was simulated by changing the irradiance input for each group of cells under the 4 bypass diodes in the model. The simulated I-V curves of the $30 \mathrm{~W}$ panel with 4 bypass diodes under different shading conditions same as shown in Figure 5 is shown in Figure 9. Given the relatively close match between the simulation and experimental results, it can be concluded that overall the simulation results in Figure 9 agree very well with the experimental results in Figure 5. Therefore, the theoretical simulation model can act as a convenient tool for predicting the panel performance under shading within a reasonable limit.
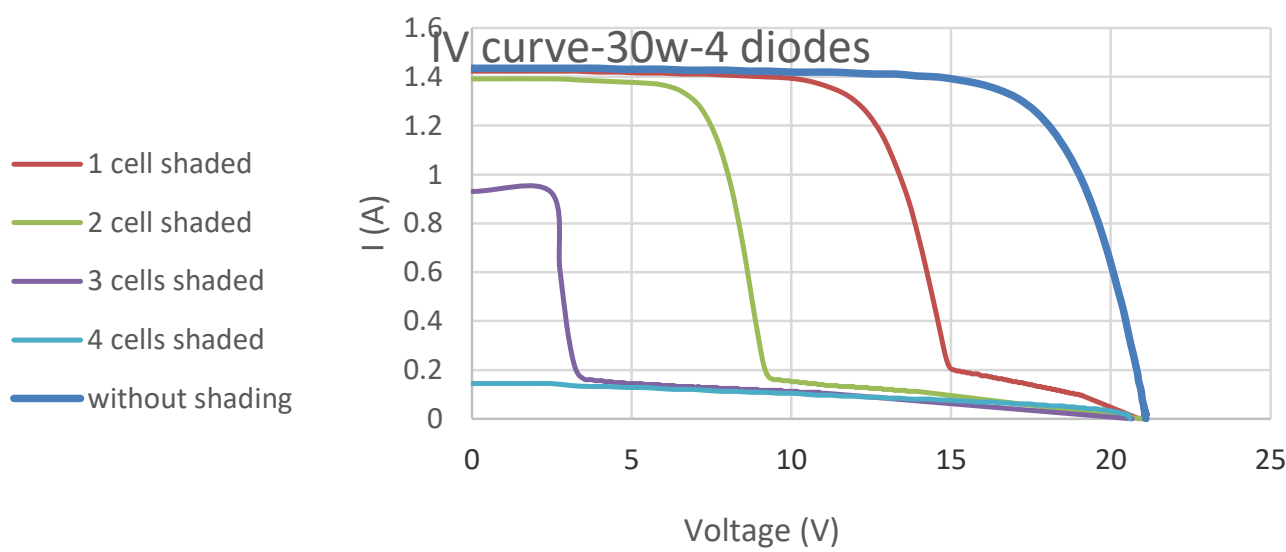

Figure 5. I-V Curves of a $30 \mathrm{~W}$ panel with 4 bypass diodes under different conditions of full cell shading 


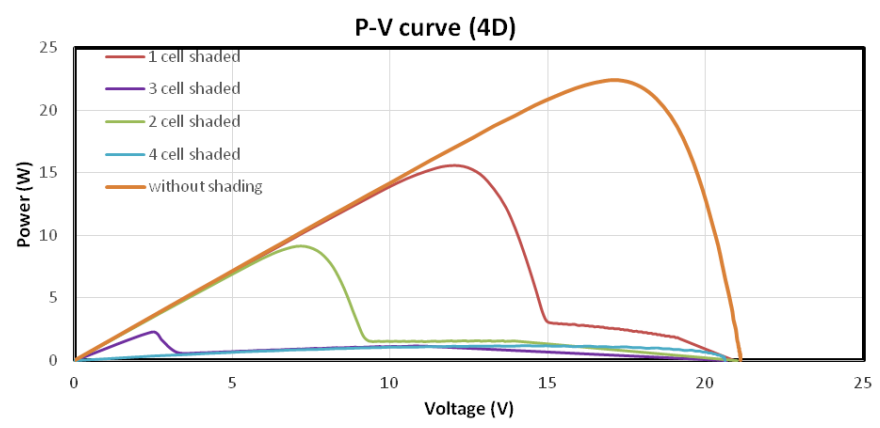

Figure 6. P-V Curves of a $30 \mathrm{~W}$ panel with 4 bypass diodes under different conditions of full cell shading

Table 2. Summary of the $30 \mathrm{~W}$ PV Panel Performance Gain with Configurations of Two and Four Bypass

\begin{tabular}{ccc}
\multicolumn{3}{c}{ Diodes Under Shading } \\
\hline Shading conditions & Irradiance $\left(\mathrm{W} / \mathrm{m}^{2}\right)$ & Gain $(\mathrm{W})$ \\
\hline Without shading & 753.9 & 0.0 \\
1 cell & 807.4 & 5.1 \\
2 cells(same diode) & 801.4 & -1.5 \\
2 cells(diff. diode) & 784.9 & 7.0 \\
3 cells & 791.9 & 0.9 \\
4 cells & 806.6 & 0.4 \\
\hline
\end{tabular}

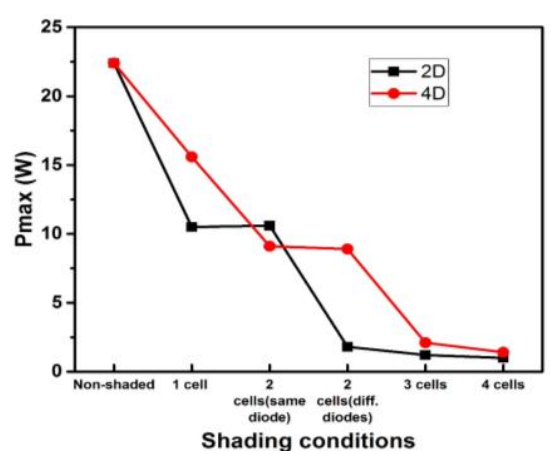

Figure 7. Maximum power of the $30 \mathrm{w}$ pv panel with two and four bypass diodes (2D and 4D) under different shading conditions

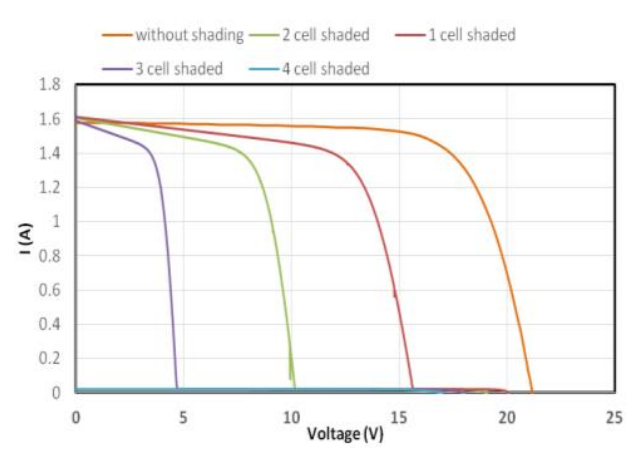

Figure 8. Simulated I-V curves of the $30 \mathrm{~W}$ panel with 4 bypass diodes under different shading conditions using simscape

\section{CONCLUSIONS}

In conclusion, from our experimental and simulation results, it can be concluded that increasing the number of bypass diodes in solar PV panels from 2 diodes to 4 diodes can improve the PV performance in the case of full cell shading. To further improve the performance of solar panels in the case of shading, subsequent study on increasing the number of diodes (e.g. connect one diode for each cell in the panel), using new types of low-voltage diodes, and adopting a more precise mathematical model (e.g. models in Simulink) will be carried out. The conclusion of the study hence can contribute to the practical photovoltaic applications in regions with uncertainty in shading conditions.

\section{ACKNOWLEDGEMENTS}

The authors would like to thank the University of Sharjah, Sharjah, United Arab Emirate and Universiti Kebangsaan Malaysia (DPP-2018-002).

\section{REFERENCES}

[1] Z. Salam, Z. Ramli, J. Ahmed, and M. Amjad, "Partial Shading in Building Integrated PV System: Causes, Effects and Mitigating Techniques," Int. J. Power Electron. Drive Syst. IJPEDS, vol. 6, no. 4, pp. 712-722, Dec. 2015. 
[2] S. Hassan, B. Abdelmajid, Z. Mourad, S. Aicha, and B. Abdenaceur, "An Advanced MPPT Based on Artificial Bee Colony Algorithm for MPPT Photovoltaic System under Partial Shading Condition," Int. J. Power Electron. Drive Syst. IJPEDS, vol. 8, no. 2, pp. 647-653, Jun. 2017.

[3] B. Ghita, K. Mohammed, and L. Ahmed, "Application and Comparison Between the Conventional Methods and PSO Method for Maximum Power Point Extraction in Photovoltaic Systems Under Partial Shading Conditions," Int. J. Power Electron. Drive Syst. IJPEDS, vol. 9, no. 2, pp. 631-640, Jun. 2018.

[4] M. Elliott, M. McIntyre, J. Lathan, and S. Tidwell, "Partial shading abatement through cell level inverter system topology," in Photovoltaic Specialist Conference (PVSC), 2015 IEEE 42nd, 2015, pp. 1-5.

[5] M. C. Alonso-García, J. M. Ruiz, and W. Herrmann, "Computer simulation of shading effects in photovoltaic arrays," Renew. Energy, vol. 31, no. 12, pp. 1986-1993, 2006.

[6] S. S. Mohammed, D. Devaraj, and T. I. Ahamed, "Modeling, simulation and analysis of photovoltaic modules under partially shaded conditions," Indian J. Sci. Technol., vol. 9, no. 16, 2016.

[7] O. G. García, J. C. Hernández, and F. Jurado, "Assessment of shading effects in photovoltaic modules," in Power and Energy Engineering Conference (APPEEC), 2011 Asia-Pacific, 2011, pp. 1-4.

[8] P. K. Mahanta, K. Debnath, and M. H. Rahman, "Modeling and Simulation of a PV Module Based Power System Using MATLAB/Simulink,” Dhaka Univ. J. Sci., vol. 62, no. 2, pp. 127-132, 2015.

[9] X. Yuan, D. Yang, and H. Liu, "MPPT of PV system under partial shading condition based on adaptive inertia weight particle swarm optimization algorithm," in Cyber Technology in Automation, Control, and Intelligent Systems (CYBER), 2015 IEEE International Conference on, 2015, pp. 729-733.

[10] K. Sundareswaran, S. Peddapati, and S. Palani, "MPPT of PV systems under partial shaded conditions through a colony of flashing fireflies," IEEE Trans. Energy Convers., vol. 29, no. 2, pp. 463-472, 2014.

[11] H. Patel and V. Agarwal, "MATLAB-based modeling to study the effects of partial shading on PV array characteristics," IEEE Trans. Energy Convers., vol. 23, no. 1, pp. 302-310, 2008.

[12] A. Kumar and K. Arora, "Effects Of Partial Shading On PV Array Characteristics Using Incremental Conductance Method," Int. J. Electr. Electron. Eng., vol. 8, no. 1, p. 948, Jun. 2016.

[13] C. Rahmann, V. Vittal, J. Ascui, and J. Haas, "Mitigation control against partial shading effects in large-scale PV power plants," IEEE Trans. Sustain. Energy, vol. 7, no. 1, pp. 173-180, 2016.

[14] F. Rong, X. Gong, and S. Huang, "A Novel Grid-Connected PV System Based on MMC to Get the Maximum Power UnderPartial Shading Conditions," IEEE Trans. Power Electron., vol. 32, no. 6, pp. 4320-4333, 2017.

[15]Suk Whan Ko, Young Chul Ju, Hye Mi Hwang, Jung Hun So, Young-Seok Jung, Hyung-Jun Song, Hee-eun Song, Soo-Hyun Kim, Gi Hwan Kang, Electric and thermal characteristics of photovoltaic modules under partial shading and with a damaged bypass diode, Energy, vol. 128 pp. 232 - 243, 2017.

[16] S. Silvestre, A. Boronat, and A. Chouder, "Study of bypass diodes configuration on PV modules," Appl. Energy, vol. 86, no. 9, pp. 1632-1640, 2009.

[17] S. Vemuru, P. Singh, and M. Niamat, "Modeling impact of bypass diodes on photovoltaic cell performance under partial shading," in Electro/Information Technology (EIT), 2012 IEEE International Conference on, 2012, pp. 1-5.

[18] E. V. Paraskevadaki and S. A. Papathanassiou, "Evaluation of MPP voltage and power of mc-Si PV modules in partial shading conditions," IEEE Trans. Energy Convers., vol. 26, no. 3, pp. 923-932, 2011.

[19] A. A. Elserougi, M. S. Diab, A. M. Massoud, A. S. Abdel-Khalik, and S. Ahmed, "A switched PV approach for extracted maximum power enhancement of PV arrays during partial shading," IEEE Trans. Sustain. Energy, vol. 6, no. 3, pp. 767-772, 2015.

[20] Sangram Bana, R.P. Saini, Experimental investigation on power output of different photovoltaic array configurations under uniform and partial shading scenarios, Energy, vol 127 pp. 438 - 453, 2017.

[21] G. N. Psarros, E. I. Batzelis, and S. A. Papathanassiou, "Partial shading analysis of multistring PV arrays and derivation of simplified MPP expressions," IEEE Trans. Sustain. Energy, vol. 6, no. 2, pp. 499-508, 2015.

[22] R. Ramabadran and B. Mathur, "Effect of shading on series and parallel connected solar PV modules," Mod. Appl. Sci., vol. 3, no. 10, p. 32, 2009.

[23] R. Ramaprabha and B. L. Mathur, "Impact of partial shading on solar PV module containing series connected cells," Int. J. Recent Trends Eng., vol. 2, no. 7, pp. 56-60, 2009.

[24] E. Karatepe, M. Boztepe, and M. Colak, "Development of a suitable model for characterizing photovoltaic arrays with shaded solar cells," Sol. Energy, vol. 81, no. 8, pp. 977-992, 2007.

[25] R. Hassan, G. Radman, and D. Gao, "User-friendly LabView tool to study effects of partial shading on PV characteristics," in Southeastcon, 2011 Proceedings of IEEE, 2011, pp. 64-67.

[26] M Al-chaderchi, K Sopain, MA Alghoul, T Salameh., Experimental study ot the effect of fully shading on the solar PV performance, E3S Web of conference, vol. 123, pp 1001, 2017. 